\title{
HABER TARTIŞMA PROGRAMLARININ BİR TÜRÜ OLARAK HABER MAHKEMELERI PROGRAMLARININ ANALIZİ: ATV, TV8, STAR TV ÖRNEĞİ
}

\begin{abstract}
Mete Kazaz*- Seher Bayar*
ÖZET

Geleneksel kitle iletişim araçlarından olan televizyon, haber verme işlevini geçmişten günümüze en etkin şekilde kullanmaktadır. İnsanların uză̆ında veya yakınında olup biten her olayı öğrenmek istemesi, haberin ve haber programlarının şekil değiştirmesine neden olmuştur. Dönüşüm geçiren haber ve haber programları içerisinde son yillarda gündüz kuşă̆ında yer alan haber mahkemeleri niteliğindeki haber-tartışma program türünün artmasına ve bu programların içeriğinin sorgulanmasına neden olmaktadır. Bu makale, "Haber Tartışma Programlarının Bir Türü Olarak Haber Mahkemeleri Programlarının Analizi"ni içermektedir. Haber kavramı ve televizyon haberciliğine değindikten sonra, Türkiye'de haber-tartışma program türünü araştıran çalışmalara yer verilmektedir. Bu bilgiler ışığında araştırmada ATV, STAR TV ve TV8'de yer alan Haber Mahkemeleri niteliğindeki programlar irdelenmektedir. Programlarda yer alan güncel konular, konuya yönelik tutumlar, adli olay durumu, telefonla katılım gibi ana başliklar içerik analizi yöntemi ile incelenerek Türkiye'de yayınlanan haber-tartışma program türü hakkında bir çerçeve çizilmeye çalışılmaktadır.

Anahtar Kelimeler: Kitle iletişim araçları, haber, televizyon haberciliği, haber-tartışma programlarn
\end{abstract}

\section{ANALYSIS OF NEWS COURT PROGRAMS AS A TYPE OF DISCUSSION PROGRAMS: EXAMPLE OF ATV, TV8, STAR TV}

\begin{abstract}
Television, which is one of the traditional mass media, uses the function of reporting in the most effective way from past to present. The fact that people want to know everything that's going on in or out of their way has caused news and news programs to change shape. In recent years, the news-discussion program, which is the subject of the news courts in the daytime, has been increasing and questioning the content of these programs.This article contains "Analysis of The Programmes of News Courts on Television". After mentioning the concept of news and television journalism, studies on the type of news-discussion program are presented in Turkey. In the light of this information, news programs in ATV, STAR TV and TV8 are examined. The current issues in the programs, attitudes towards the subject, the situation of the judicial case,
\end{abstract}

*Doç. Dr., Selçuk Üniversitesi İletişim Fakültesi, ORCID ID: https://orcid.org/0000-0002-0367-1091

** Doktora Öğrencisi, Selçuk Üniversitesi Sosyal Bilimler Enstitüsü, ORCID ID:

https://orcid.org/0000-0002-3820-520X

Makale Gönderim Tarihi: 04.10.2018 - Makale Kabul Tarihi: 05.12.2018 
Haber Tartışma Programlarının Bir Türü Olarak Haber Mahkemeleri...

participation by telephone are analyzed with content analysis and a frame is drawn about the news-discussion program Type published in Turkey.

Keywords: Mass media, news, television journalism, news-discussion programs

\section{Gírìş}

Haberleşme eylemi, yaşanılan ya da tanık olunan, merak edilen ya da öğrenilmek istenilen, aktarma ihtiyacı duyulan bilgi, duygu ve düşüncelerin diğer insanlara duyurumunu içerir (Yüksel ve Gürcan 2005: 4). Haber olgusu var olduğundan bu yana hep fiziki ve fikri anlamda birçok değişime uğramıştır.

Haberleşme ve iletişim ilk önce işaretlerle, karşıllklı şekillerle emekleme dönemini atlatmıştır. Yazının, kâğıdın, matbaanın bulunması haberleşme ve iletişimin yürüme dönemidir. Telgraf, radyo, televizyon, bilgisayar ve telefonun bulunması ise haberin hızla koşmaya başladığı bir dönemdir. Haberleşme ve haber alma ise insanın en önemli ihtiyaçlarından biri haline gelmiştir. İnsanlar kitle iletişim araçları vasıtasıyla kitleler halinde etkilenmekte, kontrol edilmekte, tüketilmekte ve üretilmektedir.

Yaşadığımız ve adım adım ilerleyerek geldiğimiz bu çağda televizyon, telefon, bilgisayar, radyo, internet vb. kitle iletişim araçları vasıtasıyla insanlar haber bombardımanına tutulmaktadır. Haber artık insanların bütün duygularına hitap etmektedir. Kitle iletişim araçlarının gelişip enformasyonun hızla yayılmasıyla haber olgusu insanlar için git gide daha da önem kazanmaktadır. Televizyon haber programları televizyonun temel metinlerinden bir tanesidir. Haberlerin üretimi, toplum yaşamı üzerindeki tahmin edilen ve sık sık da korkulan etkisi ile stratejik bir öneme sahiptir (Oğuz 2012: 225). Haberler gerçek olayların ekrana yansıması olduğu için insanlar haberlerden etkilenmekte ve sık sık güncel olayları takip etmektedir.

Televizyondaki program çeşitliliği teknolojik gelişmelerle paraleldir. Televizyon kendisinden önceki araçlardan çok farklı maddi ve teknik özelliklere sahip olduğu için, televizyon ekranına getirilen içeriklerin zamanla bu yeni araca uyarlanma gereği duyulmuş; bu sürecin sonunda da sadece televizyona özgü türler ortaya çıkmıştır (Mutlu 2008: 36). Haber mahkemeleri niteliğindeki programlar da bu değişime ayak uydurmuş televizyona özgü program türlerindendir. "Magazin Mahkemesi", "Olay yeri", "Gerçeğin Peşinde”, "Tatlı Sert" gibi isimler ile seyirci karşısına çıksa da içerik olarak haber olmaya namzet olayların mahkemeyi andıran formatlarda tartışmaya dayanan kurgu ile sunuluyor olması bu programların genel olarak "Haber Mahkemeleri Programları" olarak anılmasına sebep olmuştur. Bu çalışmada da dikkat edileceği üzere çalışmanın isminden itibaren ve sonuca ulaşıncaya kadar yine bu isimle anılacaktır.

Haberin değişim süreci de göz önüne alınarak, televizyon programlarında haber mahkemeleri niteliğindeki yayınların analizini ele alan bu çalışmada, "kitle 
iletişim araçları, televizyon haberciliği, haber-tartışma programları" arasında kurulan bağlantıyla, programlardaki güncel konuların analizine yönelik bir araştırma yapılmaktadır. Araştırmada, akademik bilgi birikimlerinden yararlanılarak, konuyla ilgili kuramsal bütünlük kurulup, bu doğrultuda televizyon programlarındaki haber mahkemeleri niteliğindeki yayınların içeriği konusunda betimleyici tespitlerde bulunulması amaçlanmaktadır.

\section{HABER KAVRAMI ve TELEVIZYON HABERCİLIĞ́̇}

İnsanların gerek yakın gerekse uzak çevrelerinde olup bitenler hakkında bilgi almalarını, günümüzde özellikle bu amaçla geliştirilmiş ve uzmanlaşmış bazı araçlar sağlamaktadır. Bu araçlara genel bir terim kullanarak kitle haberleşme araçları adını veriyoruz. Endüstri teknolojisinin gücünü simgeleyen kitle haberleşme araçları, kitleleri haberleşme ağıyla birbirine bağlamaktadırlar (Tokgöz 1994: 118). Haberleşme olgusu anlıksallaşmıştır. İnsanlar artık dünyada olup bitenleri anında haber almaktadır. İnsanlık, büyük adımlarla hiç olmadığı kadar hızla ilerlemektedir.

Haber olgusu var olduğundan bu yana fiziki ve fikri anlamda birçok değişime uğramıştır. Teknolojik gelişmelerden etkilenen haber içeriği ise günümüzde giderek görüntüye odaklı hale gelmiştir. Bol resimli kitle gazetelerinin gördügü ilgiden sonra, radyo-televizyon haberciliği hızla gelişmiştir. Modern toplumlarda televizyonun insanların günlük yaşamlarının önemli bir parçası haline gelmesi, televizyonu en önemli kitle iletişim araçlarından birisi haline getirmektedir (MEGEP 2008: 3). Bu teknolojik gelişmeler karşısında görüntüden yoksun olan haberin nesnelliği ve güvenilirliği günümüzde tartışılır boyuta gelmiştir. Haber artık insanların bütün duygularına hitap etmektedir. İnsanlar dünyanın bir ucunda yaşanan trajik bir olay yüzünden üzülebiliyor veya komik bir olaydan eğlenebiliyor hale gelmiştir.

Televizyon haberleri, ulusal ve uluslararası arenada yaşanan olayların öğrenilmesi ve anlamlandırmasında etkili ve önemli bir yere sahiptir. Değişen iletişim ortamında ve gelişen iletişim teknolojileriyle birlikte, bilgi üretimi, akışı ve dolaşımında da önemli bir artış meydana gelmiştir. Buna paralel olarak televizyon sektöründe bilgi ağırlıklı programlar ve haber bültenlerinin oranı da diğer program türleri arasında vazgeçilmez bir form olarak yer almıştır. Yeni iletişim teknolojileri ile birlikte 1980'li yıllardan sonra tüm dünyada ekonomik, politik ve kültürel alanlardaki değişimler, toplumdaki birçok yapı ve kurum ile birlikte medya endüstrilerini de etkiledi. Bu dönüşümlere paralel televizyon yayıncılığıyla birlikte haber kavramı ve televizyon haberciliği anlayışı da değişmeye başlamıştır (Karaduman ve Karaduman 2004: 247).

Dünya çapında televizyon haberleri dönüşmekte ve değişmektedir. “Kelebek etkisiyle" tüm insanlığa aynı anda ulaşabilecek ve etkileyebilecek nitelikte güce sahip olan haber, bu son halini birçok evreden ve dönemden geçerek almaktadır (Thussu 2007: 178-179, Girgin 2008: 112). Televizyon haberciliği, önceleri 
akşamdan akşama yayınlanan haber bültenleri demekti, günümüzdeyse sürekli son dakika haberleri veren, yirmi dört saat yayın yapan haber kanalları var. Avrupa'da izleyicilerin erişimine sunulan haber kanallarının toplam sayısı 162'ye ulaştı. Sadece Türkiye'de $10^{\prime}$ dan fazla haber kanalı var. Prime-time' in en çok izlenen programları arasında ilk 10' da mutlaka haber bültenleri de yer alıyor. Haberlerin bu kadar popüler olmasının nedeni ise izleyicinin haberlere anında ulaşmak istemesi ve haberi günlük yaşamının her anına yerleştirmek istemesinden kaynaklanır (Çaplı ve Tuncel 2009: 1). Haberler insan yaşamının ayrılmaz parçası haline gelmekte bu da günümüzde, konusunu gündelik yaşamdaki sorunların oluşturduğu "haber-tartışma" program türünün artan etki gücüne bağlı olarak önem kazanmaya başlamasına neden olmaktadır.

\section{HABER-TARTIŞMA PROGRAMLARI}

Günümüz modern toplumlarında doğru, hızlı ve güvenilir bilgiye ulaşmada en etkin kitle iletişim aracının televizyon olduğu bilinen bir gerçektir. Milyonlarca insan yaşadığı zaman ve mekânla ilgili bilgileri televizyon sayesinde almakta ve bu sayede televizyon haberleri de çok etkin bir işleve sahip olmaktadır. Televizyon haberleri, televizyon programları arasında en çok izlenen türlerin başında gelmesi bu türe olan önemi artırmaktadır (Karaduman 2004: 107). Haber programı, içerik esas alınarak yapılacak bir sınıflandırmaya göre, haberin bir alt türü olarak değerlendirilebilir. Haber ve haber programlarının içeriklerinin aynı olay ve konulardan oluştuğu söylenebilir, sadece konuları işleyiş tarzları farklıdır. Haber programları konuları daha uzun sürede işlerken, haberleri haftalık, on beş günlük ve aylık periyotlarla yayınlanmaktadır (Poyraz 2002: 79).

Televizyonlarda haberlere karşı ilginin artması haberlere ayrılan sürelerin son dönemde daha da ağırlık kazanması ve benzeri çeşitli gelişmeler izleyici ile haber programları arasında çok daha sık karşılaşılan bir etkileşimi de beraberinde getirmiştir. Televizyonlarda yer alan belirli haber bültenlerinin yanında, gündemde yer tutan konuların ele alınarak tartışıldığı haber programlarının da sayılarında ve çeşitlerinde artış görülmektedir. Özel televizyonların yayın hayatına başlaması ve sayılarının artması izleyicilerin kimi zaman 'gülünç', kimi zaman 'ciddi' olarak tanımladıkları haber-tartışma programlarının da özellikle son yıllarda daha fazla mercek altına yatırılmasına neden olmaktadır. Belirtilen programlarda yer verilen konuların yanında katılımcıların programlardaki davranışları, programda söz alış-katılış biçimleri; hatta, kimi sözlü ve fiziksel karşı çıkışları dikkati çekmektedir. Programlara katılanların söz almak için verdikleri çaba, tepkileri, diğer konuşmacılara karşı takındıkları tavırlar çoğu zaman programda ele alınan içeriğinin önüne geçebilmektedir (Orhon 2003: 150). Program içeriklerinin çok yoğun geçmesi ve gündemdeki olayları ele alması bakımında bu tarz program türü Türkiye'de araştırılması ve analiz edilmesi gereken program türü olarak karşımıza çıkmaktadır. Türkiye' de bu türün yeni yeni gündeme gelmesi nedeniyle de çok fazla çalışma bulunmadığı gözlenmiştir. 
'Siyaset Meydanı', 'Ateş Hattı' ve benzeri haber-tartışma programlarının analizinde program katılımcılarının görüş alıp vermede, geribildirimde bulunmada kimi anlarda özenli davranmadığı, tartışılan konuların sonuca ulaşmaktan, anlaşılır olmaktan uzaklaştığı görülmektedir. Televizyonda yer alan haber-tartışma programlarının değerlendirilmesi sonucuna bağlı olarak sıralanan ve iletişim sürecindeki geribildirim aşaması ile ilişkilendirilen noktalar, programların akışı ve izleyenin algılayabilmesi açısından da yararlı olacaktır. Bu programda tespit edilmiş sonuç önerilerinin programlardaki tartışmaları yönlendiren sunucu-yöneten tarafından öncelikle algılanması ve beraberinde katılımcılara aktarması televizyon haber-tartışma programlarının da yerleşik biçimine ve işleyişine katkıda bulunmaktadır (Orhon 2003: 153).

Poyraz, "Haber ve Haber Programlarında İdeoloji ve Gerçeklik" kitabında, 32. Gün haber programının genel özelliklerini yansıttığı düşüncesiyle Kasım 1990 bölümünü seçerek ayrıntılı bir şekilde incelemiştir. Program önerisinden, denetimine, maliyetine, formatından jeneriğine kadar derinlemesine inceleme yapan Poyraz, Türk televizyon tarihinde önemli bir yere sahip olan 32.Gün haber programına ilişkin yapılan çalışmada haber ve haber programlarının tematik yapısının anlamaya 1şık tutacağını hem de haber değeri olmadan saatlerce süren haber bültenlerinin yayınlandığını anlamanın mümkün olabileceğini savunmaktadır (Poyraz 2002: 171). Yapılan çalışmaların ortaya çıkardığ bu sonuçlar 1şı̆̆ında belki de haber tartışma programlarının içerisinde ayrı bir başlığın konusu olarak ele alınabilecek olan ve Haber Mahkemeleri formatında düzenlenen programların analizi sonucunda alana küçük de olsa bir katkı sağlanabileceği düşünülmektedir.

\section{HABER MAHKEMELERI PROGRAMLARININ ANALIZİ}

\subsection{Yöntem}

Bu araştırmada, Türkiye' de haber mahkemeleri niteliğindeki haber programları içerik analizi ile incelemiştir. İçerik analizi: "Sözel, yazılı ve diğer materyallerin içerdiği mesajı, anlam velveya dilbilgisi açısından nesnel ve sistematik olarak sinıflandırma, sayılara dönüştürme ve çıkarımda bulunma yoluyla sosyal gerçeği araştıran bilimsel bir yaklaşım" (Tavşancıl ve Aslan 2001: 17) olarak tanımlanır.

Araştırmanın örneklemini ise ATV "Müge Anlı ile Tatlı Sert", STAR "Balçiçek İlter'le Olay Yeri", TV8 “Gerçeğin Peşinde" programlarının 30 Nisan 2018-4 Mayıs 2018 tarihleri arasındaki program yayınlarının analizleri oluşturmaktadır.

Kodlama formlariyla elde edilen bilgiler SPSS 20.0 yazılımı ile elektronik ortama aktarılmış ve analiz edilmiştir. İlk kısımda kodlama formu ile elde edilen verilerin genel dağılımı verilmiş ve kanalların seçilen sorularla ilişkisi Ki Kare analizi ile incelenmiştir. 
Haber Tartışma Programlarının Bir Türü Olarak Haber Mahkemeleri...

\subsection{Bulgular}

“Haber Tartışma Programlarının Bir Türü Olarak Haber Mahkemeleri Programlarının Analizi: Atv, Tv8, Star Tv Örneği" adlı çalışmamızın bu bölümünde analizler ve bulgular yer almaktadır. Araştırmanın bulguları ve çapraz karşılaştırmaları tablolaştırılmış ve tablo yorumları yapılmıştır. ATV, STAR ve TV8' deki programların TV kanalına göre dağılımları incelendiğinde; \%36,5'i ATV, \%40,4'ü STAR, \%23,1'i ise TV8'e ait toplamda 52 programm analizi bulunmaktadir.

\subsection{Genel Bilgilerin Dağılımı}

Tablo 1. Programların TV Kanalına Göre Dağılımları

\begin{tabular}{|l|l|c|c|}
\hline \multicolumn{2}{|l|}{} & N & $\%$ \\
\hline \multirow{5}{*}{ TV Kanalı } & ATV & 19 & 36,5 \\
\cline { 2 - 4 } & STAR & 21 & 40,4 \\
\cline { 2 - 4 } & TV8 & 12 & 23,1 \\
\cline { 2 - 4 } & Total & 52 & 100,0 \\
\hline \multirow{5}{*}{ Verilis_ssıra } & 1 & 15 & 28,8 \\
\cline { 2 - 4 } & 2 & 15 & 28,8 \\
\cline { 2 - 4 } & 3 & 11 & 21,2 \\
\cline { 2 - 4 } & 4 & 5 & 9,6 \\
\hline \multirow{5}{*}{ Güncel_konular } & 5 & 4 & 7,7 \\
\cline { 2 - 4 } & 6 & 2 & 3,8 \\
\cline { 2 - 4 } & Total & 52 & 100,0 \\
\hline & Cinayet & 21 & 40,4 \\
\cline { 2 - 4 } & Dolandırıcılık & 5 & 9,6 \\
\cline { 2 - 4 } & Kaylp & 24 & 46,2 \\
\cline { 2 - 4 } & Yardım Kampanyası & 2 & 3,8 \\
\cline { 2 - 4 } & Total & 52 & 100,0 \\
\hline
\end{tabular}

Programlarda günlük yayın akışı içinde işlenen konu sayısının, veriliş sırasının dağılımına bakıldığında; 1 . ve 2. sırada olanların oranı \%28'er, 3. sırada olanların oranı $\% 21,2$, 4. sirada olanların oran $\% 9,6$ olup 5 . sirada verilenlerin oranı $\% 7,7$, 6. Sırada verilenlerin oranı ise $\% 3,8$ dir. Hafta içi 5 gün ortalama 3 saat yayınlanan programlarda günde en az 2 ile en fazla 6 konu işlenmektedir. TV8' de en fazla 2 ya da 3 konu işlenip, konulara uzun saat dilimleri ayrılırken, STAR TV' de ise gün içinde yayınlanan konu sayısı çoğu kez 6 yı bulmaktadır. Konulara verilen süre programlarda en az 3 dakika olurken, 1 saat 22 dakikayı bulan konularda olmaktadır. Güncel konunun dağılımı incelendiğinde ise; cinayet oranı $\% 40,4$, dolandirıcılık \%9,6, kayıp \%46,2 olup yardım kampanyası oran $\% 3,8^{\prime}$ dir. 
Tablo 2. Konuya Yönelik Tutum Dağılımları

\begin{tabular}{|l|l|c|c|}
\hline \multicolumn{2}{|l|}{} & N & $\%$ \\
\hline \multirow{4}{*}{ Olumlu } & Orta & 1 & 1,9 \\
\cline { 2 - 4 } & Yüksek & 2 & 3,8 \\
\cline { 2 - 4 } & Çok yüksek & 7 & 13,5 \\
\cline { 2 - 4 } & Total & 10 & 19,2 \\
\hline \multirow{4}{*}{ Olumsuz } & Orta & 3 & 5,8 \\
\cline { 2 - 4 } & Yüksek & 7 & 13,5 \\
\hline & Çok yüksek & 25 & 48,1 \\
\cline { 2 - 4 } & Total & 35 & 67,3 \\
\hline \multirow{4}{*}{ Yansız } & Orta & 5 & 9,6 \\
\cline { 2 - 4 } & Yüksek & 2 & 3,8 \\
\cline { 2 - 4 } & Total & 7 & 13,5 \\
\hline
\end{tabular}

ATV, TV8 ve STAR TV' de yayınlanan programlarda konuların çoğunluğu cinayet, kayıp ve dolandırıcilık olduğu için program yapımcılarının ve konukların konuya yönelik tutumları çoğunlukla olumsuz olmaktadır. Özellikle "kayıp" ve "cinayet" olaylarında şüpheli kişilerin stüdyoya davet edilip konuşturulması konuya yönelik olumsuz tutumun oranını artırmaktadır. Konuya yönelik tutum dağılımları incelendiğinde; olumlu tutumda orta olan $\% 1,9$, yüksek olan $\% 3,8$, çok yüksek olan ise $\% 13,5^{\prime}$ tir. Olumsuz tutuma yönelik orta seviye oranı $\% 5,8$, yüksek oranı $\% 13,5$, çok yüksek oranı ise $\% 48,1^{\prime}$ dir. Yansız tutum için orta \% 9,6, yüksek ise \% 3,8'dir.

Tablo 3. Programlarda Sonuca Ulaşma, Adli Olay Durumu, Telefonla Katılımın Dağılımı

\begin{tabular}{|l|l|c|c|}
\hline \multicolumn{2}{|l|}{} & $\mathrm{N}$ & $\%$ \\
\hline \multirow{4}{*}{ Sonuca ulaşma } & Yok & 39 & 75,0 \\
\cline { 2 - 4 } & Var & 13 & 25,0 \\
\cline { 2 - 4 } & Total & 52 & 100,0 \\
\hline \multirow{5}{*}{ Adli olay } & Yok & 37 & 71,2 \\
\cline { 2 - 4 } & Gözaltı & 9 & 17,3 \\
\cline { 2 - 4 } & Tutuklama & 5 & 9,6 \\
\cline { 2 - 4 } & Yargilama & 1 & 1,9 \\
\cline { 2 - 4 } & Total & 52 & 100,0 \\
\hline \multirow{5}{*}{ Sayı } & Yok & 31 & 59,6 \\
\cline { 2 - 4 } & Var & 21 & 40,4 \\
\cline { 2 - 4 } & Total & 52 & 100,0 \\
\hline & 1 & 10 & 47,6 \\
\cline { 2 - 4 } & 2 & 4 & 19,0 \\
\cline { 2 - 4 } & 3 & 21 & 19,0 \\
\cline { 2 - 4 } & 4 & 4,8 \\
\cline { 2 - 4 } & 5 & 2 & 9,5 \\
\cline { 2 - 4 } & Total & & 100,0 \\
\hline
\end{tabular}


Haber Tartışma Programlarının Bir Türü Olarak Haber Mahkemeleri...

Programların \%75'inde sonuca ulaşma yok iken \%25'inde sonuca ulaşılmıştır. Adli olay dağılımı incelendiğinde; adli olay olmayan programların oran $\% 71,2$, gözaltı oranı \%17,3, tutuklama \%9,6, yargılama ise \%1,9'dur. Programlarda işlenen konularda telefonla katılımlar konunun seyrini değiştirip, konunun sonuca ulaşmasını sağladığı da görülmektedir. Programların \%40,4'ünde telefonla katılım varken, \%59,6'sında telefonla katılım bulunmamaktadır. Telefonla katılım olan programlarda telefon katılım sayıları incelendiğinde; $\% 47,6$ 'sında tek telefon katılımı olmuştur. İki katılım oranı \%19, üç katılım oranı $\% 19$, dört katılım oranı $\% 4,8$ olup beş katılım oranı $\% 9,5^{\prime}$ tir.

\subsection{Kanallara Göre Karşılaştırmalar}

Tablo 4.Veriliş Sırası İle Kanal Arasındaki İlişki Dağılımı

\begin{tabular}{|c|c|c|c|c|c|c|c|c|c|}
\hline & \multicolumn{6}{|c|}{ Veriliş_sıra } & \multirow[b]{2}{*}{ Total } \\
\hline & & & 1 & 2 & 3 & 4 & 5 & 6 & \\
\hline \multirow{6}{*}{ TV Kanalı } & \multirow{2}{*}{ ATV } & $\mathrm{n}$ & 5 & 5 & 4 & 3 & 2 & 0 & 19 \\
\hline & & $\%$ & $26,3 \%$ & $26,3 \%$ & $21,1 \%$ & $15,8 \%$ & $10,5 \%$ & $0,0 \%$ & $100,0 \%$ \\
\hline & \multirow{2}{*}{ STAR } & $\mathrm{n}$ & 5 & 5 & 5 & 2 & 2 & 2 & 21 \\
\hline & & $\%$ & $23,8 \%$ & $23,8 \%$ & $23,8 \%$ & $9,5 \%$ & $9,5 \%$ & $9,5 \%$ & $100,0 \%$ \\
\hline & \multirow{2}{*}{ TV8 } & $\mathrm{n}$ & 5 & 5 & 2 & 0 & 0 & 0 & 12 \\
\hline & & $\%$ & $41,7 \%$ & $41,7 \%$ & $16,7 \%$ & $0,0 \%$ & $0,0 \%$ & $0,0 \%$ & $100,0 \%$ \\
\hline \multirow{2}{*}{\multicolumn{2}{|c|}{ Total }} & $\mathrm{n}$ & 15 & 15 & 11 & 5 & 4 & 2 & 52 \\
\hline & & $\%$ & $28,8 \%$ & $28,8 \%$ & $21,2 \%$ & $9,6 \%$ & $7,7 \%$ & $3,8 \%$ & $100,0 \%$ \\
\hline
\end{tabular}

Ki kare $=8,078 ; \mathrm{p}=0,621$

Veriliş sırası ile kanal arasındaki ilişki incelendiğinde; ATV de ilk sırada verilenlerin oranı $\% 26,3$, ikinci sırada verilenlerin oranı $\% 26,3$, üçüncü sırada verilenlerin oranı $\% 21,1$ 'dir. Dördüncü sırada verilenlerin oranı $\% 15,8$ iken beşinci sırada verilenlerin oran $\% 10,5^{\prime}$ tir. STAR TV'de ilk sırada verilenlerin ora nı 23,821,1'dir. Dördüncü sırada verilenlerin oranı \%9,5 iken beşinci sırada verilenlerin oranı $\% 9,5$, altıncı sırada verilenlerin oran $1 \% 9,5^{\prime}$ tir. TV $8^{\prime}$ de ilk sırada verilenlerin oranı $\% 41,7$, ikinci sırada verilenlerin oranı $\% 41,7$, üçüncü sırada verilenlerin oranı $\% 16,7^{\prime}$ dir. Kanal ile veriliş sırası arasında anlamlı düzeyde ilişki bulunmamaktadır ( $\mathrm{p}>0,05)$. 
Tablo 5. Kanal İle Güncel Konular Arasındaki İlişki Dağılımı

\begin{tabular}{|c|c|c|c|c|c|c|c|}
\hline & \multicolumn{4}{|c|}{ Güncel_konular } & \multirow[b]{2}{*}{ Total } \\
\hline & & & Cinayet & Dolandırıcılık & Kayıр & $\begin{array}{c}\text { Yardim } \\
\text { Kampanyası }\end{array}$ & \\
\hline \multirow{6}{*}{$\begin{array}{l}\text { TV } \\
\text { Kanalı }\end{array}$} & \multirow{2}{*}{ ATV } & $\mathrm{N}$ & 10 & 2 & 6 & 1 & 19 \\
\hline & & $\%$ & $52,6 \%$ & $10,5 \%$ & $31,6 \%$ & $5,3 \%$ & $100,0 \%$ \\
\hline & \multirow{2}{*}{ STAR } & $\mathrm{N}$ & 6 & 2 & 12 & 1 & 21 \\
\hline & & $\%$ & $28,6 \%$ & $9,5 \%$ & $57,1 \%$ & $4,8 \%$ & $100,0 \%$ \\
\hline & \multirow{2}{*}{ TV8 } & $\mathrm{N}$ & 5 & 1 & 6 & 0 & 12 \\
\hline & & $\%$ & $41,7 \%$ & $8,3 \%$ & $50,0 \%$ & $0,0 \%$ & $100,0 \%$ \\
\hline \multirow{2}{*}{\multicolumn{2}{|c|}{ Total }} & $\mathrm{N}$ & 21 & 5 & 24 & 2 & 52 \\
\hline & & $\%$ & $40,4 \%$ & $9,6 \%$ & $46,2 \%$ & $3,8 \%$ & $100,0 \%$ \\
\hline
\end{tabular}

Ki kare $=3,542 ; \mathrm{p}=0,735$

Kanal ile güncel konular arasındaki ilişki incelendiğinde; ATV'de cinayet konusu oranı $\%$ 52,6, dolandırıcilık oranı $\% 10,5$, kayıp \%31,6, yardım kampanyası oranı ise $\%$ 5,3'tür. STAR TV'de cinayet konusu oranı $\% 28,6$, dolandırıcılık oranı $\% 9,5$, kayıp \%57,1, yardım kampanyası oranı ise \% 4,8'dir. TV8'de cinayet konusu oranı $\% 41,7$, dolandırıcılık oranı $\%$ 8,3, kayıp \%50, yardım kampanyası oranı ise $\%$ 0'dir.

Tablo 6. Kanal İle Adli Olay Arasındaki İlişki Dağılımı

\begin{tabular}{|c|c|c|c|c|c|c|c|}
\hline & \multicolumn{4}{|c|}{ Adli olay } & \multirow{2}{*}{ Total } \\
\hline & & & Yok & Gözalt1 & Tutuklama & Yargilama & \\
\hline \multirow{6}{*}{$\begin{array}{l}\text { TV } \\
\text { Kanalı }\end{array}$} & \multirow{2}{*}{ ATV } & $\mathrm{n}$ & 11 & 5 & 2 & 1 & 19 \\
\hline & & $\%$ & $57,9 \%$ & $26,3 \%$ & $10,5 \%$ & $5,3 \%$ & $100,0 \%$ \\
\hline & \multirow{2}{*}{ STAR } & $\mathrm{n}$ & 18 & 0 & 3 & 0 & 21 \\
\hline & & $\%$ & $85,7 \%$ & $0,0 \%$ & $14,3 \%$ & $0,0 \%$ & $100,0 \%$ \\
\hline & \multirow{2}{*}{ TV8 } & $\mathrm{n}$ & 8 & 4 & 0 & 0 & 12 \\
\hline & & $\%$ & $66,7 \%$ & $33,3 \%$ & $0,0 \%$ & $0,0 \%$ & $100,0 \%$ \\
\hline \multirow{2}{*}{\multicolumn{2}{|c|}{ Total }} & $\mathrm{n}$ & 37 & 9 & 5 & 1 & 52 \\
\hline & & $\%$ & $71,2 \%$ & $17,3 \%$ & $9,6 \%$ & $1,9 \%$ & $100,0 \%$ \\
\hline
\end{tabular}

Ki kare $=10,819 ; \mathrm{p}=0,094$

Kanal ile adli olay arasındaki ilişki incelendiğinde; ATV'de programların $\% 57,9$ 'unda adli olay bulunmamaktadır. Gözaltı oranı \%26,3, tutuklama \%10,5, yargilama ise \% 5,3'tür. STAR TV'de programların \% 85,7'sinde adli olay bulunmamaktadır. Gözaltı oranı \%0, tutuklama \%14,3, yargılama ise $\% 0$ 'dır. TV8'de programların \% 66,7'sinde adli olay bulunmamaktadır. Gözaltı oranı \% 33,3'tür. Kanal ile adli olay arasında anlamlı düzeyde ilişki bulunmamaktadır $(\mathrm{p}>0,05)$. 
Haber Tartışma Programlarının Bir Türü Olarak Haber Mahkemeleri...

Tablo 7. Kanal İle Telefonla Katılım Arasındaki İlişki Dağılımı

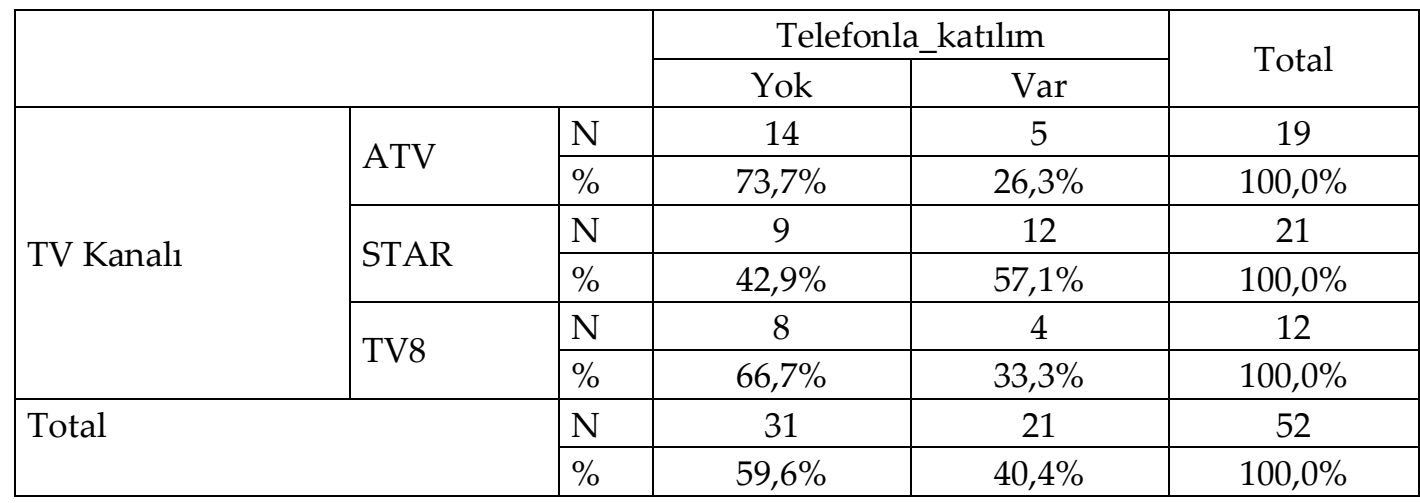

Ki kare $=4,260 ; p=0,119$

Kanal ile telefonla katılım arasındaki ilişki incelendiğinde; ATV'de \%26,3, STAR TV'de $\% 57,1$, TV8' de ise $\% 33,3$ oranında telefonla katılım olmuştur.

Tablo 8. Kanal İle Telefonla Katılım Sayısı Arasındaki İlişki Dağılım

\begin{tabular}{|c|c|c|c|c|c|c|c|c|}
\hline & \multicolumn{5}{|c|}{ Sayı } & \multirow[b]{2}{*}{ Total } \\
\hline & & & 1 & 2 & 3 & 4 & 5 & \\
\hline \multirow{6}{*}{ TV Kanalı } & \multirow{2}{*}{ ATV } & $\mathrm{n}$ & 1 & 0 & 1 & 1 & 2 & 5 \\
\hline & & $\%$ & $20,0 \%$ & $0,0 \%$ & $20,0 \%$ & $20,0 \%$ & $40,0 \%$ & $100,0 \%$ \\
\hline & \multirow{2}{*}{ STAR } & $\mathrm{n}$ & 6 & 3 & 3 & 0 & 0 & 12 \\
\hline & & $\%$ & $50,0 \%$ & $25,0 \%$ & $25,0 \%$ & $0,0 \%$ & $0,0 \%$ & $100,0 \%$ \\
\hline & \multirow{2}{*}{ TV8 } & $\mathrm{n}$ & 3 & 1 & 0 & 0 & 0 & 4 \\
\hline & & $\%$ & $75,0 \%$ & $25,0 \%$ & $0,0 \%$ & $0,0 \%$ & $0,0 \%$ & $100,0 \%$ \\
\hline \multirow{2}{*}{\multicolumn{2}{|c|}{ Total }} & $\mathrm{n}$ & 10 & 4 & 4 & 1 & 2 & 21 \\
\hline & & $\%$ & $47,6 \%$ & $19,0 \%$ & $19,0 \%$ & $4,8 \%$ & $9,5 \%$ & $100,0 \%$ \\
\hline
\end{tabular}

Ki kare $=13,282$; $\mathrm{p}=0,102$

Kanal ile telefonla katılım arasındaki ilişki incelendiğinde; ATV de tek telefon katılımı \%20 olup \%80 oranında birden fazla telefonla katılım olmuştur. STAR TV'de telefon katılımı olan programların yarısında tek telefon, yarısında ise birden fazla telefonla katılım olmuştur. TV8'de telefon katılımı olan programların \%75'inde tek telefon katılımı olup \%75'inde birden fazla katılım olmuştur.

Tablo 9. Konuya Yönelik Tutum İle Kanal Arasındaki İlişki Dağılımı

\begin{tabular}{|c|c|c|c|c|c|c|c|c|}
\hline & \multicolumn{6}{|c|}{ TV Kanalı } & \multirow{3}{*}{$\mathrm{P}$} \\
\hline & & \multicolumn{2}{|c|}{ ATV } & \multicolumn{2}{|c|}{ STAR } & \multicolumn{2}{|c|}{ TV8 } & \\
\hline & & $\mathrm{N}$ & $\%$ & $\mathrm{~N}$ & $\%$ & $\mathrm{~N}$ & $\%$ & \\
\hline \multirow{3}{*}{ Olumlu } & Orta & 1 & $12,5 \%$ & 0 & $0,0 \%$ & 0 & $0,0 \%$ & \multirow{3}{*}{0,788} \\
\hline & \begin{tabular}{|l|l} 
Yüksek \\
\end{tabular} & 2 & $25,0 \%$ & 0 & $0,0 \%$ & 0 & $0,0 \%$ & \\
\hline & \begin{tabular}{|l|} 
Çok \\
yüksek
\end{tabular} & 5 & $62,5 \%$ & 2 & $100,0 \%$ & 0 & $0,0 \%$ & \\
\hline \multirow[t]{2}{*}{\begin{tabular}{|l|} 
Olumsuz \\
\end{tabular}} & Düşük & 0 & $0,0 \%$ & 0 & $0,0 \%$ & 0 & $0,0 \%$ & \multirow[t]{2}{*}{0,636} \\
\hline & Orta & 1 & $11,1 \%$ & 1 & $6,3 \%$ & 1 & $10,0 \%$ & \\
\hline
\end{tabular}




\begin{tabular}{|c|c|c|c|c|c|c|c|c|}
\hline & Yüksek & 3 & $33,3 \%$ & 3 & $18,8 \%$ & 1 & $10,0 \%$ & \\
\hline & $\begin{array}{l}\text { Çok } \\
\text { yüksek }\end{array}$ & 5 & $55,6 \%$ & 12 & $75,0 \%$ & 8 & $80,0 \%$ & \\
\hline \multirow{3}{*}{ Yansiz } & $\begin{array}{l}\text { Çok } \\
\text { düşük }\end{array}$ & 0 & $0,0 \%$ & 0 & $0,0 \%$ & 0 & $0,0 \%$ & \multirow{3}{*}{0,476} \\
\hline & Orta & 1 & $50,0 \%$ & 2 & $66,7 \%$ & 2 & $100,0 \%$ & \\
\hline & Yüksek & 1 & $50,0 \%$ & 1 & $33,3 \%$ & 0 & $0,0 \%$ & \\
\hline
\end{tabular}

Konuya yönelik tutum ile kanal arasındaki ilişki incelendiğinde; ATV'de olumlu tutumda orta düzey oranı $\% 12,5$, yüksek oranı $\% 25$, çok yüksek oranı $\% 62,5^{\prime}$ tir. STAR TV'de tamamı çok yüksektir. Olumlu tutum düzeyi ile kanal arasında anlamlı düzeyde ilişki bulunmamaktadır $(\mathrm{p}>0,05)$.

Olumsuz tutum düzeyi ile kanal arasındaki ilişki incelendiğinde; ATV'de orta düzey $\% 11,1$, yüksek $\% 33,3$, çok yüksek ise $\% 55,6$ 'dır. STAR TV'de orta $\% 6,3$, yüksek $\% 8,8$, çok yüksek $\% 75^{\prime}$ tir. TV8'de orta $\% 10$, yüksek $\% 10$, çok yüksek ise $\% 80$ 'dir. Olumsuz tutum düzeyi ile kanal arasında anlamlı düzeyde ilişki bulunmamaktadir $(\mathrm{p}>0,05)$.

Yansız tutum düzeyi ile kanal arasındaki ilişki incelendiğinde; ATV' de yarısı orta yarısı yüksektir. STAR TV'de \%66,7'si orta, \%33,3'ü ise yüksektir. TV8'de ise tamamı orta düzeydedir. Yansız tutum düzeyi ile kanal arasında anlamlı düzeyde ilişki bulunmamaktadır ( $\mathrm{p}>0,05)$.

\section{SONUÇ}

Haber kavramı günümüze kadar birçok evreden geçmiş ve değişime uğramıştır. İnsanların haber ihtiyaçlarını karşılamak ve her istedikleri an gündemdeki olayları takip edebilmesi için tematik haber kanalları kurulmuştur. İhtiyaca göre değişime ve dönüşüme uğrayan haberin son hali olan "haber mahkemeleri niteliğindeki haber programları" çalışmanın temelini oluşturmaktadır.

Günümüzde haber ve haber programları günlük hayatta insanların en sık takip ettiği program türü varsayımından yola çıarak içerik analizi yapılan 52 programin \%36,5'i ATV, \%40,4'ü STAR, \%23,1'i ise TV8'e aittir. Programlarda en fazla işlenen konu ise, \%40,4 oranı ile cinayettir. Bunu \%46,2 oranında kayıp, $\% 9,6$ dolandırıcılık, \%3,8 yardım kampanyası takip etmektedir.

Kanalların güncel konulara yönelik tutumu, \%48, 1 oranında olumsuz-çok yüksektir. Kanallarda genellikle cinayet ve kayıp haberleri ağırlıkta olduğu için program sunucularının genellikle "konuyla bağlantısı olduğu düşünülen insanları" program davet etmeleri programda olumsuz havanın esmesine neden olmaktadır.

Analizi yapılan programlarda \%75'inde sonuca ulaşma yok iken \%25'inde sonuca ulaşılmıştır. Sonuca ulaşılan konularda ise, gözaltı oranı $\% 17,3$, tutuklama $\% 9,6$, yargılama ise $\% 1,9^{\prime}$ dur. En fazla gözaltı oranı $26,3 \%$ ile 5,3\% yargılama oranı ile ATV Müge Anlı ile Tatlı Sert programında olurken, en fazla tutuklama 
oranı 14,3\% ile Star TV Balçiçek İlter'le Olay Yeri programına aittir. Programlarda bir konu en ince ayrıntısına kadar işlenmektedir. Muhabirler olay yerine gönderilmekte ve olay yerinden canlı yayınlarla yayına bağlanmaktadır. Telefonla katılımda programdaki konunun seyirini değiştirebilmektedir. Telefonla katılım sonucunda kayıplar bulunabilmekte ya da cinayet hakkında bilgi verilebilmektedir. Telefonla katılım olan programlarda telefon katilım sayıları incelendiğinde; \%47,6'sında tek telefon katılımı olmuştur. İki katılım oranı \%19, üç katılım oranı \%19, dört katılım oranı $\% 4,8$ olup beş katılım oranı $\% 9,5^{\prime}$ tir.

Programlarda, avukat, psikolog ve bazen de adli tıp uzmanları bulunduğu gözlenmiştir. Her konu ile programa başvuru yapan taraflar ve çelişki cevaplar vererek şüpheleri üstüne çeken kişiler yer almaktadır. ATV ve STAR TV' de yer alan programlarda yardım kampanyaları olması da dikkat çekmektedir. Ayrıca ATV Müge Anlı ile Tatlı Sert programı sosyal sorumluluk projelerine yer vermekte ve bu projelerle gündeme gelmektedir.

Güncel haber-tartışma programları içerisinde ayrı bir başlığın konusu olarak ele alınabilecek olan ve Haber Mahkemeleri formatında düzenlenen programlar hakkında bir çerçeve çizmeye çalışan bu araştırma, konuyla ilgili yapılması planlanan araştırmalara temel bazı betimleyici bilgiler sunmayı hedeflemiştir. Yapılan içerik analizi ve elde edilen bulgularla haber-tartışma program türünde hangi konuların ağırlıkta işlendiği, konuya yönelik tutum, adli olay durumu, program sayısı gibi birçok genelleyici veriye ulaşılabilmeyi mümkün kilmaktadir.

\section{KAYNAKÇA}

Aslan E ve Tavşancıl E (2001) Sözel, Yazılı ve Diğer Materyaller İçin İçerik Analiz ve Uygulama Örnekleri, Epsilon Yayıncılık, İstanbul.

Çaplı B ve Tuncel H (2009) Televizyon Haberciliğinde Etik, Fersa Matbaacılık, Ankara.

Girgin A (2008) Gazeteciliğin Temel İlkeleri, Der Yayınları, İstanbul.

Karaduman S ve Karaduman M (2004) Bilgi Toplumunun Oluşmasında Televizyon Haberlerinin Yeri ve Önemine İlişkin Eleştirel Bir Bakış, 3. Ulusal Bilgi, Ekonomi ve Yönetim Kong, 25-26 Kasım 2014, Eskişehir.

Karaduman S (2004) Küreselleşen Televizyon Haberciliği Anlayışı Üzerine Bir Değerlendirme, Akdeniz Üniversitesi İletişim Fakültesi Derg, 1, 05-123.

MEGEP (2008) TV Haber Yazımı, http://megep.meb.gov.tr/mte_program_modul/moduller_pdf/tv\%20haber\%20yaz 1m1.pdf, erişim tarihi: 13. 09. 2018.

Mutlu E (2008) Televizyonu Anlamak (2.Baskı) Ayraç Kitapevi, Ankara. 
Oğuz G Y (2012) Televizyon Haberlerinde Temsil Sorunu: Kadınlar Haberin Neresinde?, Ömer Özer (edt), Haberi Eleştirmek, Literatürk, Konya, 217-246.

Orhon E N (2003) Televizyon Haber-Tartışma Programları Ve Geribildirimin Katılımcılar Tarafından Uygulanma Biçimleri, Kurgu Derg, 20, 149-154.

Poyraz B (2002) Haber ve Haber Programlarında İdeoloji ve Gerçeklik, Ütopya Yayınevi, Ankara.

Thussu D K (2007) News as Entertainment The Rise of Global Infotainment, Sage Puplication, London, Singapore, New Delhi, California.

Tokgöz O (1994) Temel Gazetecilik (7.baskı), İmge Kitabevi Yayınları, Ankara.

Yüksel E ve Gürcan H İ (2005) Haber Toplama ve Yazma (1.Bask1), Tablet Kitabevi, Konya. 